(C) О.В. Тебенко, 2010

ISSN 2076-8184. Інформаційні технології і засоби навчання. 2010. №5 (19).

Режим доступу до журналу: http://www.ime.edu-ua.net/em.html

УДК 681.3;377.4

Тебенко Олександр Віталійович, провідний інженер відділу електронних інформаційних ресурсів і мережних технологій Інституту інформаційних технологій i засобів навчання НАПН України, м. Київ

\title{
ВСТАНОВЛЕННЯ І НАЛАШТУВАННЯ САЙТУ НА СИСТЕМІ SНАRЕРОINT
}

\section{Анотація}

Засоби для створення сайтів, що надають користувачам можливість для зручного керування контентом сайту, $\epsilon$ актуальною темою в період розвитку інформаційного суспільства. У статті розглянуто систему SharePoint, за допомогою якої можна створювати сайти будь-якого рівня складності, у тому числі великі портали зі складною структурою документообігу. Метою статті $є$ аналіз основних процесів створення сайту та його налагодження за допомогою системи SharePoint, a саме, створення i налаштування шаблону сайту, створення веб-застосувань, організація середовища для створення та налаштування веб-застосувань, зміна існуючої та створення нової теми сайту, налаштування веб-частин.

Ключові слова: SharePoint, сайт, система управління сайтом, інформаційна система, Інтернет, портал, веб-частина, веб-застосування.

Вступ. Основною проблемою у сучасному інформаційному середовищі під час створення сайту є пошук ефективних та зручних інструментів для керування контентом сайту. Служби SharePoint допомагають у вирішенні даного питання, надаючи потужний набір інструментів для організації даних, управління документами, зовнішнім виглядом сайту, створення надійного середовища взаємодії.

Аналіз останніх досліджень і публікацій. Останні публікації щодо системи Microsoft SharePoint представлені у роботах Ольги Лондер, Біла Інгліша, Тодда Блікера, Пенелопи Ковентрі.

Метою даної статті є розгляд процесу створення сайту та його налагодження за допомогою системи Microsoft SharePoint, а саме, робота з шаблоном, розробка вебзастосувань, організація середовища для створення та налаштування веб-застосувань, робота з темою сайту: зміна існуючої та створення нової, робота з веб-частинами. 
У наш час досить великим попитом користуються складні сайти з вбудованими засобами роботи з різними типами документів та можливістю забезпечення спільної роботи користувачів. Найпопулярніша технологія проектування сайтів PHP-MySQLApache не передбачає таких засобів і створювати їх потрібно практично із самого початку. Актуальною темою $є$ використання технологій і платформ, де ці засоби вже передбачені архітектурою конкретної системи. Представником таких систем $\epsilon$ продукт Microsoft SharePoint. Це функціональне веб-застосування для платформи MSSQL-IIS. Проектування сайтів 3 допомогою SharePoint $\epsilon$ дуже перспективним напрямком для України, тому детальний аналіз і приклади роботи системи $\epsilon$ надзвичайно актуальними.

Виклад основного матеріалу дослідження. Microsoft SharePoint, відома також як Microsoft SharePoint Products and Technologies - система управління вмістом сайту 3 інтегрованою функцією пошуку, що розроблена компанією Microsoft, дозволяє користувачам спільно працювати з документами у веб-середовищі. Тобто користувач без додаткових програмних засобів, використовуючи браузер, може завантажувати документи, вносити до них корективи та відображати зміни іншим учасникам. SharePoint має багато вбудованих можливостей, а також дозволяє стороннім розробникам вносити модифікації для розширення функціоналу, що дає можливість створювати сайти будь-якого рівня складності.

SharePoint представлений у вигляді двох основних продуктів:

- Windows SharePoint Services (WSS) - безкоштовний додаток до Windows Server. WSS надає базову інфраструктуру для спільної роботи, редагування, зберігання документів, контролю версій та інше;

- Microsoft Office SharePoint Server (MOSS) - платний компонент для інтеграції функціональності SharePoint в роботу додатків MS Office та для розширення можливостей WSS.

Далі під поняттям SharePoint будемо розуміти розширену версію MOSS 2007 або систему в цілому.

Створення видавничого порталу. Видавничий портал - тип сайтів SharePoint для публікації веб-сторінок, який містить бібліотеки документів для зберігання публікацій у мережі, функції для спільного редагування веб-сторінок та інше. Цей тип сайтів було обрано для розробки порталу інформаційної системи «Планування 
наукових досліджень в Академії педагогічних наук України на базі мережі Інтернет», робота якого потребує суттєвих змін як в дизайні, так і в структурі системи за замовчуванням, складного механізму розмежування доступу до сторінок та бібліотеки документів. Проте, більшість питань, описаних у статті, актуальні для проектування порталів на базі системи SharePoint.

SharePoint дозволяє створювати велику кількість незалежних один від одного сайтів. Це можуть бути сайти як на одному доменному імені (http://organization.ua/sites/portal1/, http://organization.ua/sites/portal2/), так і на різних (http://portal1.ua/, http://portal2.ua/).

Для створення нового сайту в уже існуючому в системі доменному імені потрібно зайти в Central Administration (веб-орієнтована адміністративна утиліта SharePoint) та в розділі Application Management / SharePoint Site Management натиснути Create site collection. Отримаємо форму з полями, що потрібні для попереднього налагодження сайту: заголовок, адреса, мова, шаблон та адміністратора. Основні поля, на яких потрібно додатково зупинитися:

- Адреса. За замовчуванням можна створювати новий сайт тільки в каталозі /sites/. Додати новий каталог (наприклад, /department/) можна на сторінці Define Managed Paths. Це потрібно тільки для естетичного вигляду адреси сайту, на функціонування (розбиття на каталоги) це не впливає. Тобто створюється повноцінний, окремий робочий сайт, який може мати свій унікальний вигляд та, навіть, іншу мову. У випадку ж створення нового сайту в уже існуючій колекції, наприклад: http://organization.ua/department/library/books, де books - адреса сайту в library, дані можуть і будуть успадковані від library.

- Мова. SharePoint підтримує багатомовність за допомогою так званих мовних пакетів, що завантажують локалізовані переклади для стандартних шаблонів та компонент системи. Завантажити файли можна на сайті Microsoft, у тому числі й українську версію.

- Шаблон. Шаблон, у контексті SharePoint - це набір компонентів та можливостей, які підключаться автоматично під час створення сайту. Шаблони, як і мовні файли, можуть бути підключені до системи додатково. Але є стандартний набір, якого, у більшості випадків, цілком достатньо. Щоб створити сайт для повноцінного документообігу потрібно обрати шаблон Publishing Portal (видавничий 
портал). Для порівняння функціональних можливостей для адміністраторів видавничого порталу i, наприклад, веб-блогу, було створено два сайти з різними шаблонами, результат чого показано на рис. 1. Як видно з рис. 1, адміністратор видавничого порталу може створювати підсайти, керувати користувачами та їхніми правами щодо контенту на сайті, формувати звіти та інше [1, с. 402].
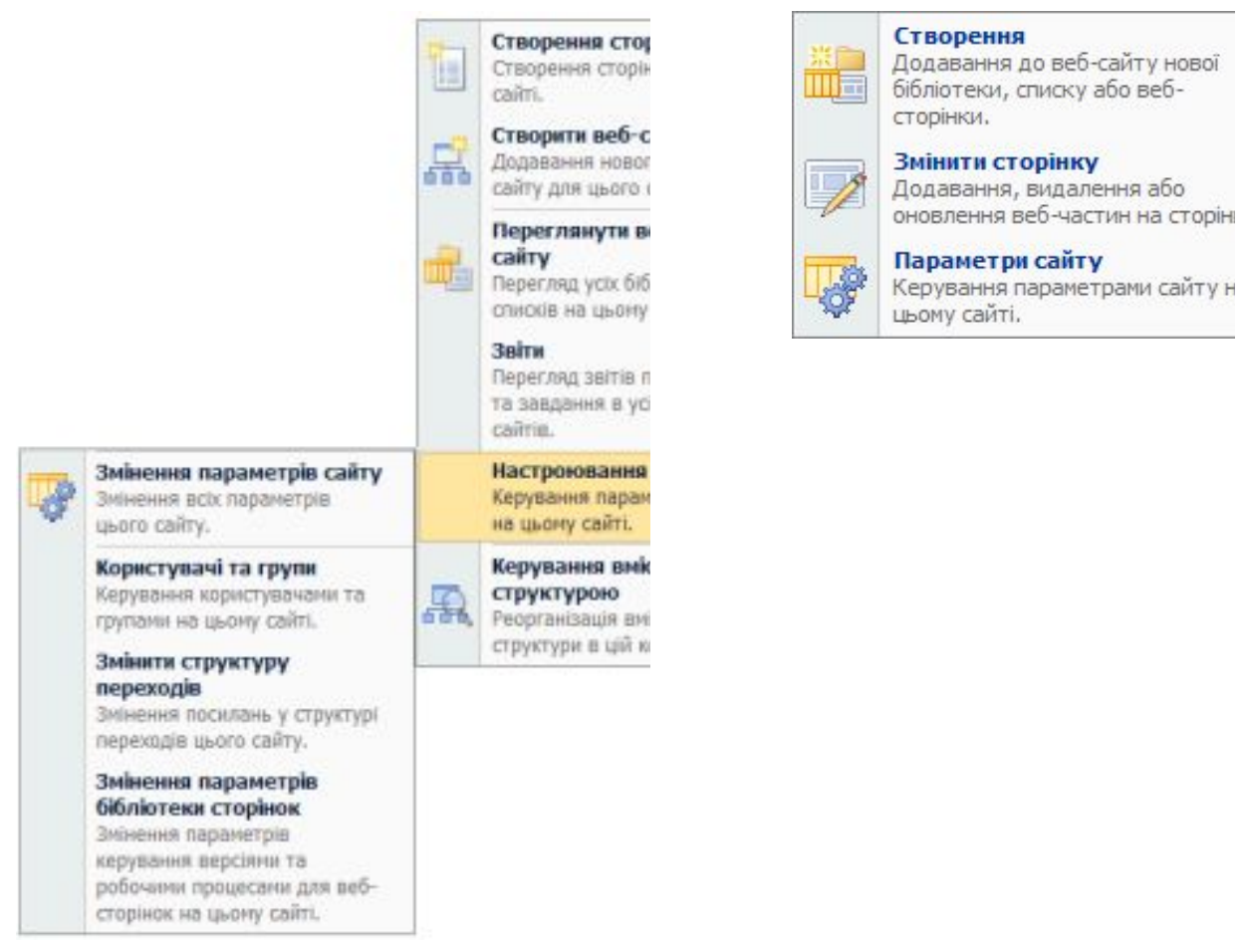

Рис. 1. Різниия у функціональних можливостях для адміністратора різних типів сайту: меню адміністратора видавничого порталу ліворуч, а веб-блогу - праворуч

Якщо ж потрібно створити сайт на новому доменному імені, потрібно спочатку створити веб-застосування (Web application) - розширити віртуальний сервер. Для цього використовується команда extendvs утиліти stsadm.exe, приклад застосування якого подано на рис.2.

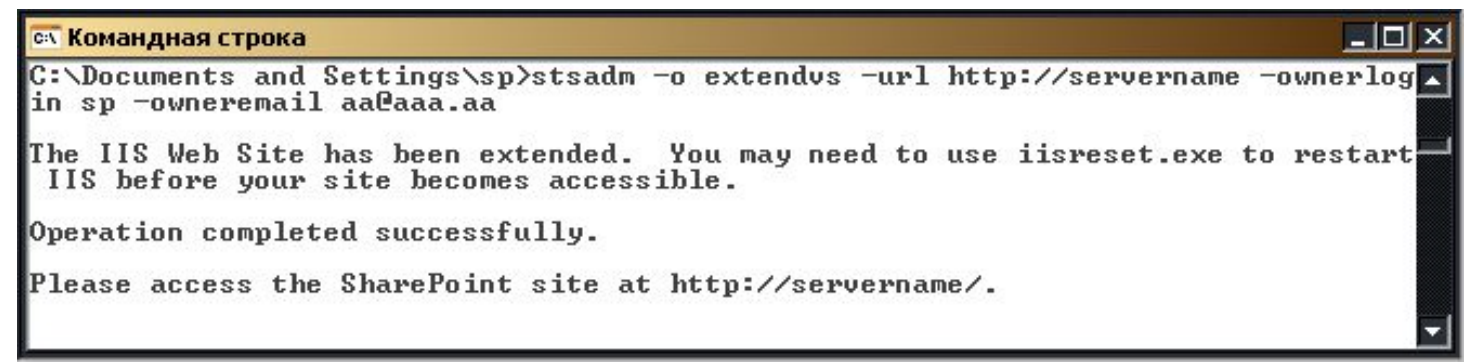

Рис. 2. Приклад створення нового веб-застосування утилітою stsadm.exе 
Примітка 1: утиліта stsadm.exe знаходиться в C:IProgram Files $\backslash$ Common Files\Microsoft Sharedlweb server extensions\12〈BIN, тобто цей шлях повинен бути прописаний у системній змінній РАТН.

Примітка 2: можна використати й інші додаткові параметри, повний список яких можна отримати, набравши stsadm -о extendvs, найважливішим серед яких $є$ параметр -donotcreatesite, який дозволяє створювати веб-застосування без створення сайту верхнього рівня (/). У такому випадку сайт верхнього рівня потрібно буде створити через сторінку Create site collection, але при цьому, нові сайти можна буде створювати безпосередньо в каталозі «/», тобто http://organization.ua/Site1, http://organization.ua/Site2.

SharePoint під час створення нового сайту, залежно від обраного шаблону, встановлює стандартну тему. Вигляд Видавничого порталу показано на рис. 3. Зрозуміло, що дизайн та функціонал під потреби кожної організації повинен бути зміненим, перш за все, для зручності користувачів.

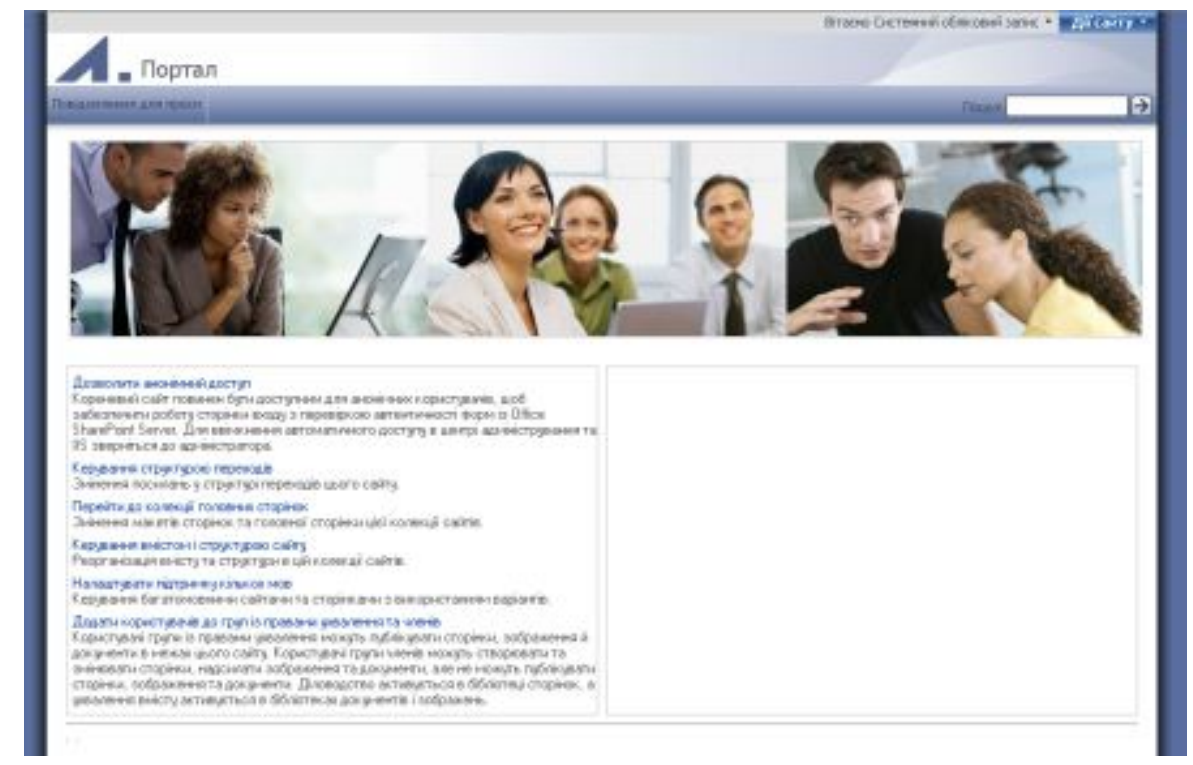

Рис. 3. Стандартний вигляд Видавничого порталу

Інструментарій для налагодження сайту SharePoint

Розглянемо інструменти, за допомогою яких можна вносити зміни в налаштування сайту (див. рис. 4).

Браузер - власне основний інструмент для роботи із системою. Низка можливостей SharePoint забезпечує адміністраторам можливість налаштування зовнішнього вигляду та функціоналу сайту за допомогою:

- зміни логотипу; 
- зміни стандартних зображень;

- зміни теми сайту;

- налагодження веб-частин та підключення нових компонентів.

Microsoft SharePoint Designer (SPD) - безкоштовний WYSIWYG HTMLредактор і програма для веб-дизайну від компанії Microsoft, що дозволяє:

- налагоджувати сайти SharePoint в потрібному вигляді: вибирати формат і вміст сторінок SharePoint, використовуючи технології ASP.NET, діючих вебстандартів (таких як XHTML) та каскадних таблиць стилів;

- створювати інтерактивні веб-сторінки без програмування: до складу програми включено повний комплект засобів для інтеграції даних у сторінки SharePoint і подання цих даних у сайтах SharePoint з використанням XSLT;

- створювати робочі процеси: до складу програми включено конструктор робочих процесів - потужного і простого в застосуванні інструменту, що дозволяе налаштовувати користувальницькі умови та дії робочих процесів, пов'язувати їх 3 даними SharePoint та ін.

Зрозуміло, що без SharePoint Designer практично не можливі будь-які серйозні зміни в сайтах.

Microsoft Visual Studio - середовище розробки та налаштування веб-сайтів на основі Windows SharePoint Services, за допомогою якого можна створювати, наприклад, Windows програми, консольні застосування і бібліотеки класів, вебзастосування для роботи браузером (так звані "ASP.NET веб-сайти) та веб-служб, які реалізують об'єктну модель Windows SharePoint Services. Нижче наведено перелік типових технологій Microsoft, які будуть використані в розробці:

- Microsoft ASP.NET для розробки додаткових функцій;

- XML для обміну даними;

- HTML для відтворення сторінок сайту;

- XSLT для взаємодії з XML даними;

- Microsoft ADO.NET для отримання даних із серверних систем;

- C\#, Microsoft Visual Basic .NET або будь-яка інша мова, що сумісна 3 Microsoft. NET Framework;

- Microsoft Visual Basic or ECMAScript (Microsoft JScript або JavaScript код) для розробки функціональності на стороні користувача. 


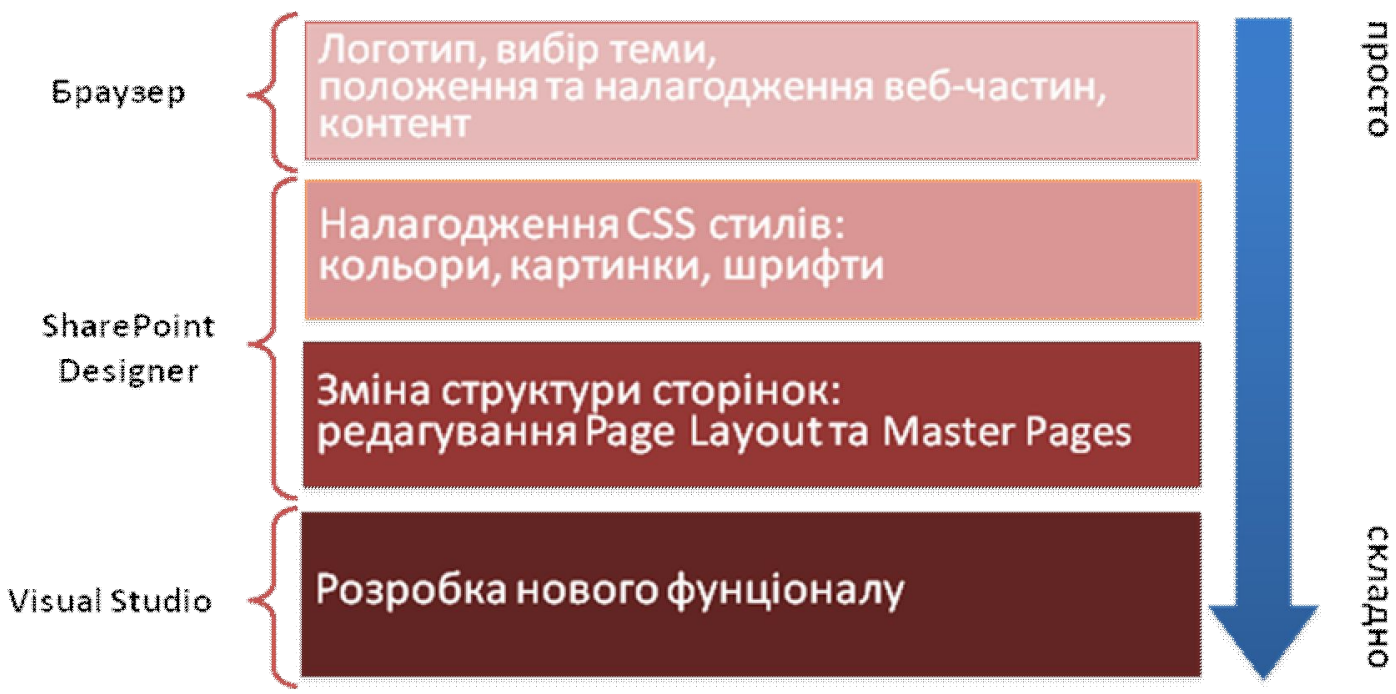

Puc. 4. Інструменти налаштування SharePoint

Етап 1. Налаштування сайту за допомогою браузера

Зміна логотипу. Для початку потрібно завантажити зображення до бібліотеки зображень сайту «Рисунки», доступ до якої можна отримати через «Весь вміст сайту». Припустимо, що було завантажено картинку logo.jpg, тоді посилання на логотип має такий вигляд http://servername/PublishingImages/logo.jpg. Далі слід перейти до розділу Параметри сайту -> Заголовок, опис і піктограма, де в полі URL-адреса й опис емблеми прописати потрібний шлях (див. рис. 5).
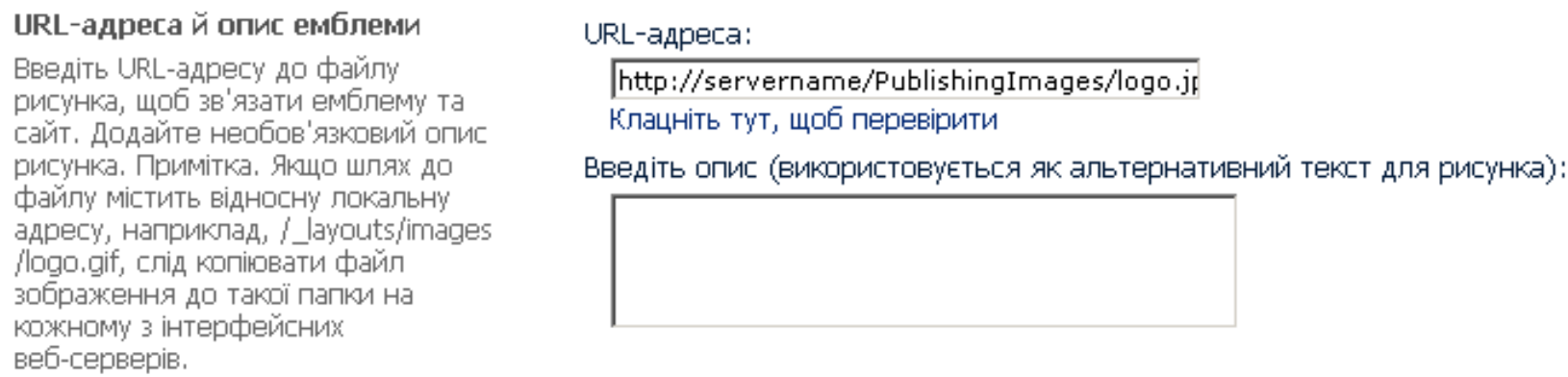

Рис. 5. Форма зміни логотипу сайту

Зміна теми сайту. Тема - це уніфікований набір елементів оформлення, які впливають на шрифти та кольорову гаму сайту. Зміна теми сайту - це найпростіший спосіб налаштування сайту відповідно до особливостей організації. Для Зміни теми сайту необхідно перейти в Параметри сайту та в розділі Зовнішній вигляд обрати пункт меню Тема сайту, з наведеного списку обрати потрібну тему [2, с. 110]. Приклад зміни теми показано на рис. 6. Додаткові теми можна завантажити на сайті компанії Microsoft. 


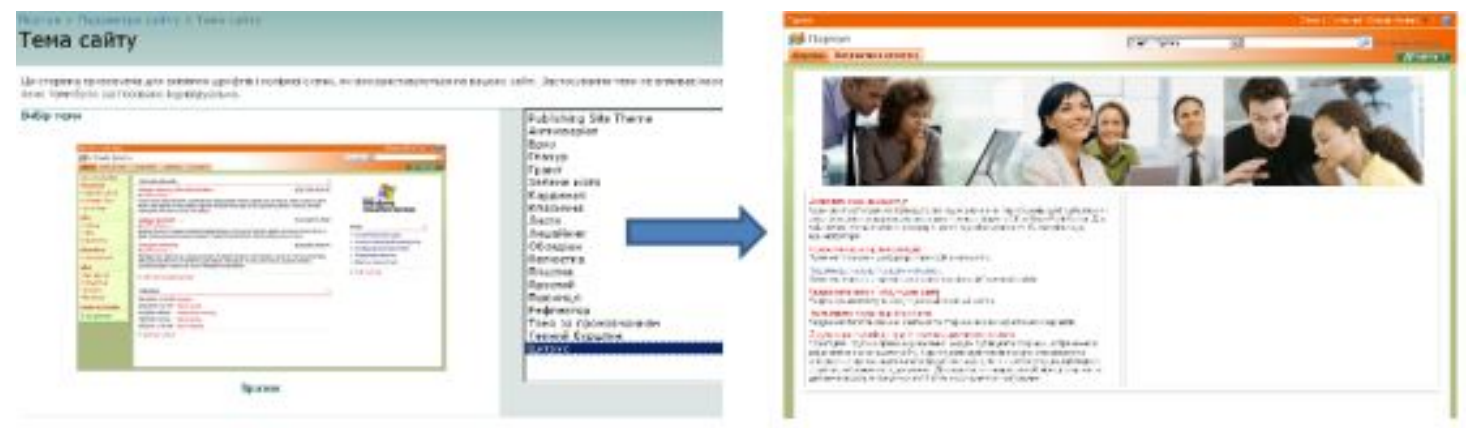

Рис. 6. Список доступних тем - ліворуч, результат зміни теми сайту - праворуч

Налаштування веб-частин. Для внесення змін у налаштування веб-частин потрібно перейти в режим редагування сторінки, на якій ці зміни будуть відбуватися $[3$, c. 123]:

- $\quad$ натиснути на кнопку Дії сайту Діїсайту - в правому верхньому кутку сторінки, щоб викликати меню адміністратора сайту (див. рис. 1);

- $\quad$ натиснути Змінити сторінку.

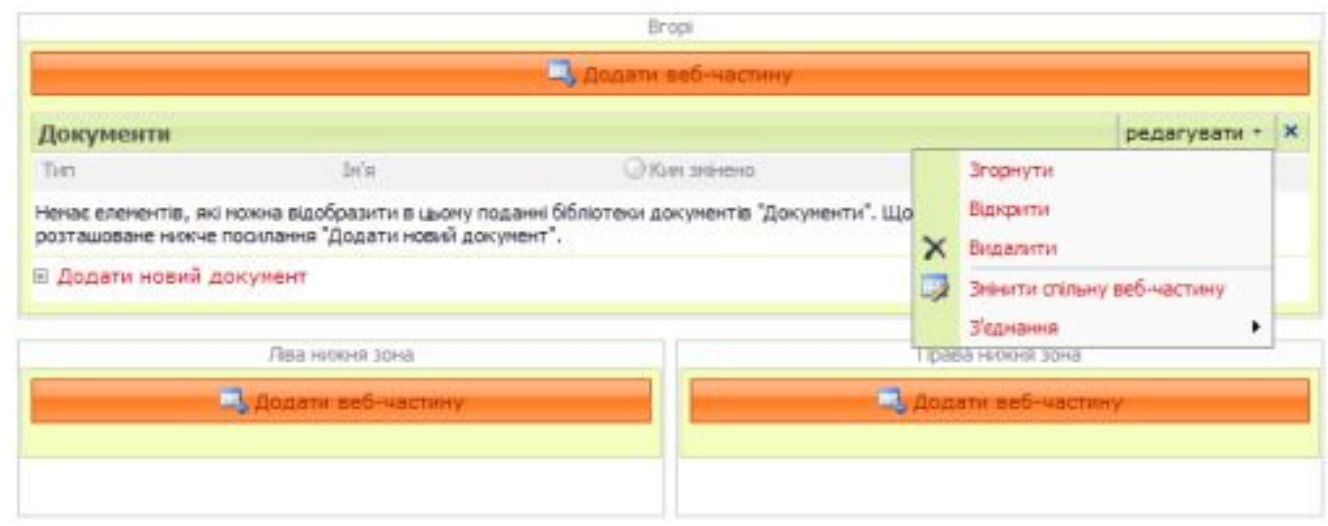

Рис. 6. Блоки веб-частин, меню редагування веб-частини

Після чого активується режим редагування сторінки. Зазвичай на сторінці $є$ декілька зон, у які можна додавати веб-частини (див. рис. 6). Ці зони мають видимі межі, заголовок та спеціальну кнопку Додати веб-частину, після натискання на ній 3'явиться вікно (див. рис. 7) зі списком усіх можливих веб-частин у системі. Щоб змінити параметри веб-частини, потрібно викликати меню редагування (рис. 6) та натиснути на пункт меню Змінити спільну веб-частину. 


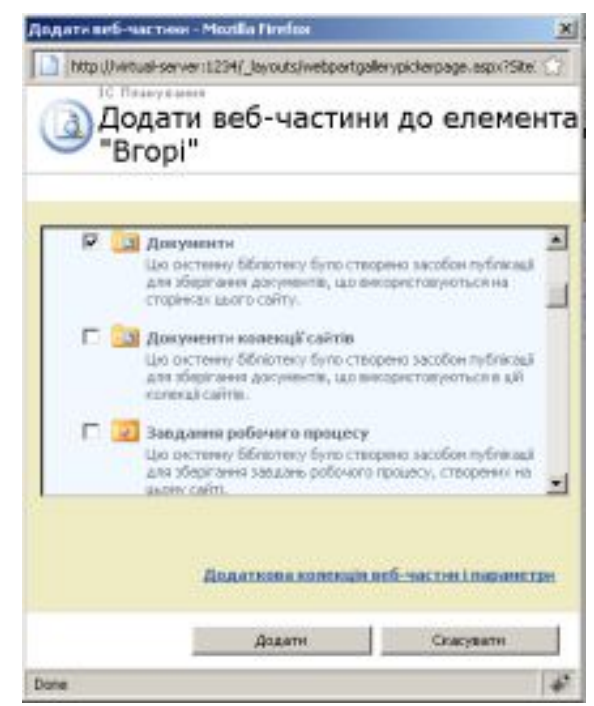

Рис. 7. Вікно вибору веб-частин при додаванні

Після додавання нових веб-частин та внесення змін у існуючі веб-частини, сторінку обов’язково потрібно опублікувати, інакше для інших користувачів буде відображатися стара версія.

Етап 2. Налаштування тем SharePoint

Другий етап внесення змін на сайті (див. рис. 4) потребує від користувача базових знань веб-дизайну (HTML та CSS).

Зміни в існуючій темі. Щоб отримати доступ до зображень, стилів та налаштувань теми потрібно запустити програму SharePoint Designer та під’єднатися до потрібного вузла (для російськомовної версії програми): Файл -> Открыть узел... і вибрати необхідний елемент зі списку доступних вузлів або в полі Имя узла ввести адресу сайту та натиснути Oткрыть (див. рис. 8).

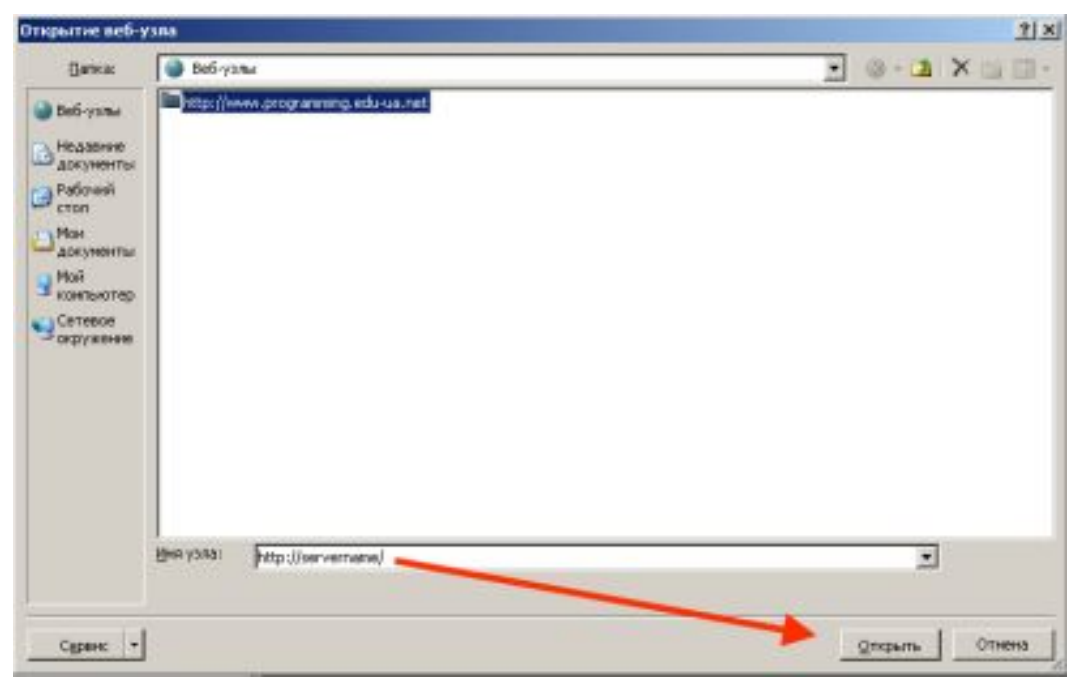

Рис. 8. Відкриття веб-вузла 
Після вдалої авторизації ліворуч у блоці Список папок повинна відобразитись інформація щодо сайту, який редагується ( див. рис. 9).

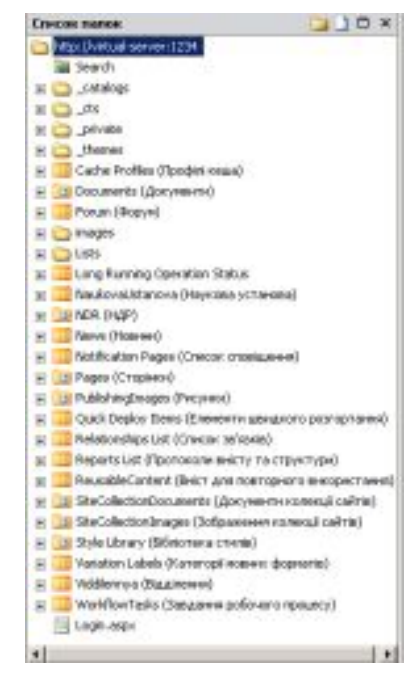

Рис. 9. Перелік списків та папок сайту

Налаштування теми, яка зараз застосована на сайті, знаходяться в папці_themes/НазваТеми (див. рис. 10):

- З Зображення. Подвійне натискання лівою кнопкою миші на зображенні відкриє редактор, який дозволяє внести та зберегти зміни.

- Стилі. А саме theme.css та згенерований файл *1011-65001.css (об'єднує копію theme.css та інших файлів стилів, що застосовуються на сайті).

Примітка: під час редагування головного файлу theme.css ніяких змін на сайті виконано не буде, тому що SharePoint завантажує єдиний файл теми *1011-65001.css.

Система працює так: спочатку завантажуються стандартні стилі SharePoint, потім завантажуються стилі теми, які перевизначають стандартні. Тобто, якщо, наприклад, очистити файл стилів - отримаємо стандартну тему SharePoint. Повний перелік стилів з описом та прикладами можна отримати за посиланнями:

- http://www.heathersolomon.com/content/sp07cssreference.htm;

- http://msdn.microsoft.com/en-us/library/ms916805.

- Файл налаштувань НазваТеми.inf. За допомогою цього файлу можна змінити основні властивості теми, зокрема: назву, версію, формат та інше, але на зовнішній вигляд теми це не впливає. 


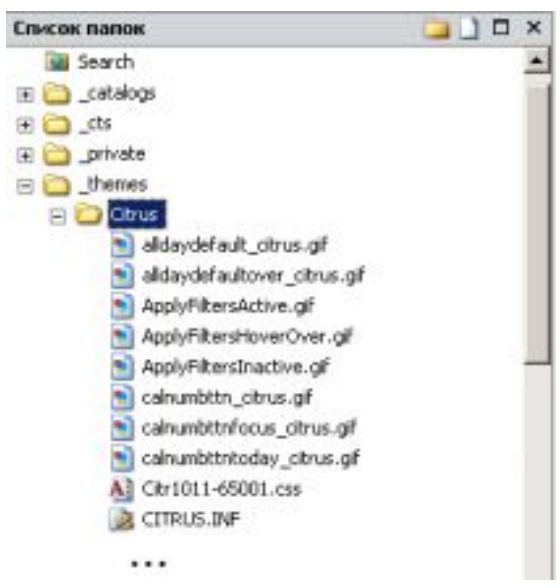

Рис. 10. Список зображень, стилів та налаштувань теми

Створення нової теми. Внесення змін в існуючій темі не завжди є доцільним, наприклад, у разі вибору іншої теми, навіть, якщо потім повернутися до теми, що редагувалася, - зміни будуть втрачені, адже SharePoint завантажує оригінальні файли зі сховища. Також тему, що редагувалася, не можна буде використати на інших сайтах. Тому доцільно обрати тему, що найбільше підходить та на їі основі зробити нову. Отже, для створення нової теми, потрібно:

1. Скопіювати та перейменувати папку теми. Теми зберігаються в папці THEMES: $\quad$ C:IProgram $\quad$ Files\Common $\quad$ Files\Microsoft $\quad$ Sharedlweb $\quad$ server extensions\12\TEMPLATEITHEMES.

2. Перейменувати файл .inf так, щоб ім’я файлу співпадало з ім’ям створеної теки - назвою теми.

3. Відкрити файл .inf і замінити назву теми.

4. Змінити CSS - themes.css. У даному випадку редагується саме файл themes.css - оригінальний файл стилів теми.

5. Змінити зображення.

6. Створити попередній вигляд для теми і покласти до 12\TEMPLATE\Images.

7. Додати оголошення теми у SPTHEMES.xml в папку 2ІTEMPLATELLayouts\1033.

Водночас важливо зауважити:

- частина зображень не доступні для зміни за допомогою механізму зміни теми;

- сайт не буде успадковувати тему батьківського сайту. Для кожного новоствореного сайту, тему необхідно застосовувати заново;

- якщо themes.css було змінено, для того щоб побачити ці зміни, тему потрібно заново застосувати. 
Висновки. У статті показано, що систему SharePoint доцільно застосовувати в якості платформи для створення сучасних освітніх порталів, оскільки за його допомогою можна оптимально реалізувати обмін даними між користувачами, що дуже важливо в процесі навчання та вирішення наукових проблем. У результаті аналізу системи SharePoint визначено концепції та методи побудови сайтів і порталів будь-якого рівня складності з можливістю спільної роботи користувачів. Такий підхід використовується у проектуванні інформаційної системи «Планування наукових досліджень в Національній академії педагогічних наук України на базі мережі Інтернет». Водночас подана методика може застосовуватися для розробки інших інформаційних систем і порталів як у галузі освіти, так в інших предметних галузях.

\section{Список використаних джерел}

1. Ноэл M., Спенс K. Microsoft SharePoint 2007. Полное руководство. - М.: Вильямс, 2008. - 832 с.

2. Лондер О., Бликер T. и др. Службы Microsoft Windows SharePoint. Шаг за шагом. - М.:СП «Эком», 2005. - 376 с.

3. Тэд Паттисон, Дэниэл Ларсон. Внутреннее устройство Microsoft Windows SharePoint Services 3.0 - М.: Питер, 2008. - 448 c.

4. Документація по Windows SharePoint Services SDK від компанії Microsoft. [Електронний ресурс]. - Режим доступу: http://msdn.microsoft.com/en-us/sharepoint/ default.aspx - Заголовок з екрана.

\section{УСТАНОВКА И НАСТРОЙКА САЙТА SHАRЕРОINT}

\section{Тебенко А. В.}

\section{Аннотация}

Средства для создания сайтов, предоставляющих пользователям возможность для совместной работы, являются актуальной темой в условиях информационного общества и современных веб-технологий. В статье рассмотрена система SharePoint, с помощью которой можно создавать сайты любого уровня сложности, в том числе крупные порталы со сложной структурой документооборота. Целью статьи является анализ основных процессов создания сайта и его отладки с помощью системы SharePoint, а именно, создание и настройка шаблона сайта, создание веб-приложений, среда для создания и настройки веб-приложений, изменение существующей и создание новой темы сайта, настройки веб-частей. 
Ключевые слова: SharePoint, сайт, система управления сайтом, информационная система, Интернет, портал, веб-приложение, веб-часть.

\section{SHAREPOINT SITE CREATING AND SETTING}

\section{Tebenko $O$.}

\section{Resume}

Tools for sites building that offer users the ability to work together, an actual theme in information society and modern Web technologies. This article considers the SharePoint system, which enables to create sites of any complexity, including large portals with a complex structure of documents. Purpose of this article is to consider the main points of site creating and its setting with tools of SharePoint system, namely: a site template creating and configuring, web application environment to create and configure Web applications, change of existing and creation of new theme site, a web part setting.

Keywords: SharePoint, site, content manager system, information system, Internet, portal, web application, web-part. 